\title{
A prospective clinical study of management of pregnancy complicated with intauterine fetal death by low dose prostaglandins
}

\author{
Nandkishor Vithalrao More*, Bhaurao Bhimrao Yadav, Mangla Ashok Shinde
}

Department of Obstetrics and Gynecology, Government Medical College, Latur, Maharashtra, India

Received: 08 July 2017

Accepted: 29 July 2017

\section{*Correspondence:}

Dr. Nandkishor Vithalrao More,

E-mail: nandkishormore@gmail.com

Copyright: () the author(s), publisher and licensee Medip Academy. This is an open-access article distributed under the terms of the Creative Commons Attribution Non-Commercial License, which permits unrestricted non-commercial use, distribution, and reproduction in any medium, provided the original work is properly cited.

\begin{abstract}
Background: This study was conducted to evaluate the effectiveness and side effects of Prostaglandins (vaginal misoprostol) in the termination of second and third trimester pregnancies complicated with intrauterine fetal death.

Methods: This study was carried out on 100 women with intrauterine fetal demise in second and third trimester pregnancies collected from Government Medical college and Hospital during the period October 2014 to October 2016.

Results: By the application of $25 \mu \mathrm{g}$ of misoprostol in the posterior fornix of vagina every 4 hourly over 24 hours. The progress, adverse effects and outcomes were assesed. The success rate was $92.76 \%$ and $64.52 \%$ in women with third and second trimesters respectively. The mean induction delivery interval was $15.67 \pm 9.64$ and $24.94 \pm 8.23$ for women with third and second trimesters respectively. The induction delivery interval correlated negatively with the duration of gestation. The mean value of total required dose was $192.42 \pm 128.99$ and $361.29 \pm 139.92$ for women with third and second trimesters respectively.

Conclusions: Low dose misoprostol appears to be safe, effective, practical and inexpensive method for termination of third trimester pregnancies compared to second trimester complicated with intauterine fetal death and its effects increases with duration of gestation.
\end{abstract}

Keywords: Intrauterine fetal death, Misoprostol

\section{INTRODUCTION}

The management of termination of pregnancy involving a dead fetus or one with a lethal anomaly is a challenge and poses dilemma for Obstetrician in any setting. The frequency of intrauterine fetal death with a retained fetus varies, but is estimated to occur in $1 \%$ of all pregnancies. This clinical situation is psychologically stressful for the women and her family members. When a fetus dies in the uterus options for obstetrician are either to await onset of spontaneous labor or to induce labor. ${ }^{1}$ In cases where expectant management is chosen, the complications will be the development of disseminated intravascular coagulation with its inherent risk of hemorrhage, blood components transfusion and even maternal death. The danger of complications like amniotic embolism is also greater. $^{2}$

Induction of labor is a common and evidence based practice of obstetrics in case of IUFD, therefore the decision to induce labor in a patient with ripe cervix is straightforward and the procedure often uncomplicated. But complexity increases if Bishop score $<6$ which leads to failed induction and higher risk of cesarean delivery. ${ }^{3}$ Oxytocine and intra-amniotic instillation of prostaglandins were used in this situation, but they are not suitable because ineffectiveness in stimulating the uterus in preterm and risk of sepsis respectively., ${ }^{4,5}$ These problems are drastically reduced with local and systemic use of prostaglandins. 
Misoprostol, a synthetic analogue of prostaglandin $E_{1}$, is effective and inexpensive, stable at room temperature, easy to administer, and does not require direct supervision during the induction. Now it has become a gold standard drug in obstet practice because its ability to bring about cervical changes and uterine contractions. Large evidences show that use of misoprostol for labor induction is highly efficacious and safe, in which vaginal route is most effective than oral as it bypasses the first pass metabolism. ${ }^{4}$

Oral misoprostol administration for labor induction with an IUFD was first described in Sao Paulo, Brazil in 1887 since then it grows widely. ${ }^{6}$ There are $n$ number of reports, statements, reviews and meta analyses for its use for induction with live fetuses. Unfortunately, there is lack of uniformity in the doses for its use in IUFD and remain so due to concern of fetal wellbeing with live fetuses.

In view of the above, this study is undertaken with the aims to evaluate the effectiveness and side effects of repeated vaginal administration of small doses of misoprostol in termination of second and third trimester pregnancies complicated with IUFD. ${ }^{3}$

\section{METHODS}

The present prospective study is carried out in Department of Obstetrics and Gynecology in Government Medical College and Hospital, during the period from October 2014 to October 2016.

\section{Inclusion criteria}

- Patient with IUFD with gestational age from 13 weeks to term, with absent spontaneous labour pain and Bishop score $\leq 9$.

- Patient with IUFD with gestational age from 13 weeks to term, with spontaneous labour pain and Bishop score $>6$.

- Group-I: Pregnancies from gestational age 13 weeks to 26 weeks (second trimester) complicated with IUFD as documented by USG report.

- Group-II: Pregnancies beyond 26 weeks of gestational age (third trimester) complicated with IUFD as documented by USG report.

\section{Exclusion criteria}

Patients were excluded if they had a prior myometrial incision, bronchial asthma, cardiovascular, renal or hepatic diseases and complications like DIC, amniotic embolism, shock.

The size of study cases was 100 .

Detail history, thorough clinical examination, counseling and written consent were carried out and patient were subjected to carry out termination of pregnancy. The induction regimen includes application of misoprostol 25 $\mu \mathrm{g}$ tablet in the posterior fornix of the vagina every 4 hours (upto 6 doses) after determination of Bishop score. If the first dose does not lead to effective contractions the subsequent dose could be doubled to $50 \mu \mathrm{g}$ to $100 \mu \mathrm{g}$ after 4 hours. If no efficient regular uterine contractions occurred after 6 doses, augmentation of uterine contractions to be done by oxytocin drip, 4 hours after last misoprostol dose. Recording the total dose of misoprostol received and the need for surgical interference to remove the dead fetus or the retained placenta or both. The induction trial was considered successful when induction delivery interval was less than 24 hours. Failure of delivery within 24 hours is considered "failed trial" but it's not indication to stop the trial i.e. the trial will be completed till termination. The following parameters were noted like number of doses, escalation of doses, induction delivery interval, success rate, failed induction and maternal complications.

\section{RESULTS}

The total number of patients assigned for the study were 100, which were divided into two groups as second trimester (T2) and third trimester (T3). There are 31 patients in T2 and 69 patients in T3. The qualitative data are expressed in the form of percentage and quantitative data in the form of mean \pm standard deviation (SD) and $\mathrm{P}$ value. Table 1 shows that majority of the cases in the present study belong to 21-25 years age group with the range 18-35 years.

Table 1: Age distribution.

\begin{tabular}{|lll|}
\hline Age (yrs) & T2 $\mathrm{n}(\%)$ & $\mathrm{T} 3 \mathrm{n}(\%)$ \\
\hline$\leq 20$ & $5(16.1 \%)$ & $9(13.0 \%)$ \\
\hline $21-25$ & $13(41.9 \%)$ & $33(47.8 \%)$ \\
\hline $26-30$ & $11(35.5 \%)$ & $21(30.4 \%)$ \\
\hline$\geq 31$ & $2(6.5 \%)$ & $6(8.7 \%)$ \\
\hline Total & $31(100.0 \%)$ & $69(100.0 \%)$ \\
\hline
\end{tabular}

Table 2 shows the distribution of cases according to the required number of doses of Misoprostol for induction by vaginal route. Majority of cases in T2 group needed 6 doses whereas majority in T3 group needed 1-3 doses, with a mean of $4.80 \pm 1.10$ and $3.17 \pm 1.65$ respectively which is highly significant with a $\mathrm{P}$ value of 0.012 .

Table 2: Response to dosage of drug.

\begin{tabular}{|ll|l|}
\hline No. of doses & T2 $\mathrm{n}(\%)$ & T3 $\mathrm{n}(\%)$ \\
\hline 1 & $0(0)$ & $13(18.8)$ \\
\hline 2 & $1(3.2)$ & $15(21.7)$ \\
\hline 3 & $2(6.5)$ & $13(18.8)$ \\
\hline 4 & $10(32.3)$ & $12(17.4)$ \\
\hline 5 & $7(22.6)$ & $7(10.1)$ \\
\hline 6 & $11(35.5)$ & $9(13.0)$ \\
\hline Total & $31(100.0)$ & $69(100.0)$ \\
\hline Mean \pm SD & $4.80 \pm 1.10$ & $3.17 \pm 1.65$ \\
\hline
\end{tabular}

$\mathrm{T}$ value $=1.14 ; \mathrm{P}$ value $=0.012(<0.05)(\mathrm{HS})$ 


\section{DISCUSSION}

As per the observations from Table 1 it is evident that majority of the cases in the present study belong to 21-25 years age group with the range of 18-35 years. Table 2 shows that the distribution of cases according to the required number of doses of misoprostol for induction by vaginal route.

Majority of cases in T2 group needed 6 doses whereas in T3 needed 1-3 doses with mean of $4.80 \pm 1.10$ and $3.17 \pm 1.65$ respectively which is highly significant with a $\mathrm{P}$ value of $0.012 .^{6}$ The present study is consistent with studies of Alhawary TS et al and Ezechi OC et al. ${ }^{4,7}$

Table 3: Escalation of doses.

\begin{tabular}{|lll|}
\hline Doses in $\mu \mathrm{gg}$ & $\mathrm{T} 2 \mathrm{n}(\%)$ & $\mathrm{T} 3 \mathrm{n}(\%)$ \\
\hline 25 & - & $47(68.11)$ \\
\hline 50 & $9(29.03)$ & $22(31.88)$ \\
\hline 100 & $22(70.96)$ & - \\
\hline Total & 31 & 69 \\
\hline
\end{tabular}

Table 4: Induction delivery interval in relation to gestational age.

\begin{tabular}{|lll|}
\hline $\begin{array}{l}\text { Induction delivery } \\
\text { interval (Hrs) }\end{array}$ & $\mathrm{T} 2 \mathrm{n}(\%)$ & $\mathrm{T} 3 \mathrm{n}(\%)$ \\
\hline $1-10$ & $0(0 \%)$ & $29(42.0 \%)$ \\
\hline $11-20$ & $9(29.0 \%)$ & $26(37.7 \%)$ \\
\hline $21-30$ & $15(48.4 \%)$ & $9(13.0 \%)$ \\
\hline $31-40$ & $6(19.4 \%)$ & $2(2.9 \%)$ \\
\hline$>41$ & $1(3.2 \%)$ & $3(4.3 \%)$ \\
\hline Total & $31(100.0 \%)$ & $69(100.0 \%)$ \\
\hline Mean SD & $24.94 \pm 8.23$ & $15.67 \pm 9.64$ \\
\hline Range & $12-48.50$ & $3.55-48.00$ \\
\hline
\end{tabular}

$\mathrm{T}$ value $=1.02 ; \mathrm{P}$ value $=0.307(>0.05)(\mathrm{NS})$

Table 3 shows about $70 \%$ cases in $\mathrm{T} 2$ needed increased dosage upto $100 \mu \mathrm{g}$, whereas T3 only $50 \mu \mathrm{g}$. Table 4 shows that about $50 \%$ of the cases in T2 group delivered within $21-30$ hours, whereas $80 \%$ of the cases in T3 delivered in 20 hours.

Table 5: Induction delivery interval in relation to parity.

\begin{tabular}{|c|c|c|}
\hline $\begin{array}{l}\text { Induction delivery } \\
\text { interval (Hrs) }\end{array}$ & $\begin{array}{l}\text { Primigravida } \\
\mathrm{n}(\%)\end{array}$ & $\begin{array}{l}\text { Multigravida } \\
\text { n }(\%)\end{array}$ \\
\hline $1-10$ & $20(40.0 \%)$ & $9(18.0 \%)$ \\
\hline $11-20$ & $17(34.0 \%)$ & $18(36.0 \%)$ \\
\hline $21-30$ & $9(18.0 \%)$ & $15(30.0 \%)$ \\
\hline $31-40$ & $1(2.0 \%)$ & $7(14.0 \%)$ \\
\hline$>40$ & $3(6.0 \%)$ & $1(2.0 \%)$ \\
\hline Total & $50(100.0 \%)$ & $50(100.0 \%)$ \\
\hline Mean \pm SD & $16.70 \pm 10.38$ & $20.38 \pm 9.65$ \\
\hline
\end{tabular}

The mean induction delivery interval for $\mathrm{T} 2$ was $24.94 \pm 8.23$ and T3 was $15.67 \pm 9.64$ which is statistically significant and consistent with studies by Nikintu $\mathrm{N}$ et al, Alhawary TS et al. ${ }^{4,8}$ The Inverse relationship between gestational age and induction delivery interval has been confirmed in this study.

Table 5 shows that induction delivery interval in primigravida was lesser than multigravida with a mean of $16.70 \pm 10.38$ and $20.38 \pm 9.65$ respectively. The $p$ value is 0.024 which is significant and correlates with the study of Tang OS et al. ${ }^{9}$

Table 6: Success rate and failed induction.

\begin{tabular}{|lll|} 
Gestational age & $\begin{array}{l}\text { Failed induction } \\
n(\%)\end{array}$ & $\begin{array}{l}\text { Success rate } \\
n(\%)\end{array}$ \\
\hline T2 & $11(35.48 \%)$ & $20(64.52 \%)$ \\
\hline T3 & $5(7.24 \%)$ & $64(92.76 \%)$ \\
\hline Total & 16 & 84 \\
\hline
\end{tabular}

Table 6 shows that failed induction in second trimester is $35.48 \%$ whereas in third trimester it is $7.24 \%$. Hence success rate is $64.52 \%$ and $92.76 \%$ respectively, which is statistically significant and again proves the inverse relation of gestational age and induction delivery interval.

Table 7: Maternal complications-tachysystole.

\begin{tabular}{|ll|}
\hline Gestational age & Tachysystole $\mathrm{n}(\%)$ \\
\hline T2 & $3(9.6 \%)$ \\
\hline T3 & $2(2.8 \%)$ \\
\hline Total & $5(12.4 \%)$ \\
\hline
\end{tabular}

Table 7 shows that the incidence of tachysystole was more in patients whose induction delivery interval was more than 20 hours and who required a total dose of misoprostol of more than $300 \mu \mathrm{g}$. This shows that the complications occur more frequently with increased total dose of misoprostol.

\section{CONCLUSION}

The present study concludes that low dose misoprostol is a safe, effective, practical and inexpensive method for termination of third trimester pregnancies compared to second trimester pregnancies complicated with intrauterine fetal death.

Funding: No funding sources

Conflict of interest: None declared

Ethical approval: The study was approved by the Institutional Ethics Committee

\section{REFERENCES}

1. Silver TM. Fetal death. Obstet Gynecol. 2007;109:153-67. 
2. Darney PD, Neal L, Fong K. Absorption kinetics of misoprostol. Obstet Gynecol. 1997;90:88-91.

3. Rodolfo Gomez,Deborath Wing, Christian Finala WHO Misoprostol guidlines. Draft 2/11/2007; Chapter 8: p 1-8.

4. Alhawary TS, El-Gharib SH. Elshourbagy clinical medicine insights. Women's Health. 2010;3:15-21.

5. Raghwan KS. Prostaglandins in Labour, chapter-13. $1^{\text {st }}$ Edn. Managment of labour. Edt- S. S. Rathnam and K.Bhaskar Rao 2001;197-212.

6. Mariani-Neto C, Kenj G. Use of misoprostol for induction of labor in stiilbirths. Rev Paul Med. 1987;105(6):325-8.

7. Ezechi OC, Kalu Bke, Ndububa VI, Induction of labour by vaginal misoprostol for intra uterine fetal death. J Obstet Gynecol Ind. 2004;54(6):561-3.
8. Nikintu N. A study of vaginal misoprostol and intravenous oxytocin for induction of labor in management of IUFD. Afr Health Sci. 2001;1(2):559.

9. Tang OS, Schweer H, Seyberth HW, Lee SW, Ho PC. Pharmacokinetics of different routes of administration of misoprostol. Hum Reprod. 2002;17(2)332-6.

Cite this article as: More NV, Yadav BB, Shinde MA. A prospective clinical study of management of pregnancy complicated with intauterine fetal death by low dose prostaglandins. Int J Reprod Contracept Obstet Gynecol 2017;6:3788-91. 